\title{
The Use of a Write-Pair-Square Strategy to Improve The Students' Active Participation in Writing Descriptive Text
}

Dwi Arni Siti Margiyanti

Kesatrian 2 Semarang Senior High School, Indonesia

e-mail: mdwiarni@yahoo.co.id)

\begin{abstract}
Many problems faced by students in participating in the classroom and writing a text. This study discussed the use of write-pair-square strategy to improve the students' active participation in writing descriptive text. The objectives of the study are to find out the implementation of writepair-square in teaching descriptive text and to investigate the improvement of students' participation and writing achievement after being taught by using write-pair-square strategy. The research focused on teaching of descriptive text by using write-pair-square as the strategy. The subjects are SMA Kesatrian 2 Semarang students. This study used Classroom Action Research that was carried out through a pre-test, first and second cycle activities. The result showed that the students' progress of participation improved. The average score of pre-test was 11.27, post-test 1 was 20.13 , and post-test 2 was 30.24 . It also showed that students' mastering descriptive improved. The average achievement of students' pretest was63.27, First cycle test was70.23and post test was 77.66. According to this study, I conclude that teaching descriptive text by using write-pair-square as the strategy is helpful for students. It is recommended for English teachers to use Write-pair-square as the strategy for students' improvement of their writing skill.
\end{abstract}

Keywords: Teaching Descriptive Text, Write Pair Square, Active Participation 


\begin{abstract}
Abstrak
Banyak masalah yang dihadapi oleh siswa dalam mengikuti pembelajaran dan menulis teks. Penelitian ini membahas tetang penggunaan strategi write-pair-square untuk meningkatkan partisipasi aktif dari siswa dalam menulis teks.Objek dari studi ini adalah untuk mendeskripsikan penerapan write-pair-square dalam mengajar teks deskriptif dan untuk menyelidiki peningkatan partisipasi siswa dan prestasi menulis setelah diajar dengan menggunakan strategi write-pairsquare. Penelitian ini berfokus pada pengajaran teks deskriptif dengan menggunakan strategi write-pair-square. Sedangkan subjek penelitian ini adalah siswa SMA Kesatrian 2 Semarang. Dengan menerapkan penelitian tindakan kelas, penelitian dilakukan melalui pre-test, serta aktivitas siklus pertama dan kedua. Penelitian menunjukkan terdapat peningkatan partisipasi siswa. Skor rata dari pre-test adalah 11, 27, post-test 1 sebanyak 20,13, dan post-test 2 sebanyak 30,24. Ini menunjukkan bahwa kemampuan siswa dalam menguasai teks deskriptif meningkat. Rata-rata prestasi siswa pada pre-test adalah 63, 27. Sedangkan pada siklus pertama adalah 70, 23 dan pada post-test sebanyak 77, 66. Berdasarkan studi ini, penulis menyimpulkan bahwa pengajaran teks deskriptif dengan menggunakan strategi write-pair-square dapat membantu siswa dalam pembelajaran. Sehingga, disarankan kepada guru bahasa Inggris untuk menggunakan strategi tersebut guna peningkatan kemampuan menulis siswa.
\end{abstract}

Kata Kunci: Pengajaran Teks Deskriptif, Write-Pair-Square, Partisipasi Aktif

\title{
Introduction
}

Teaching writing in traditional way is still can be found in many schools. Harmer (2004) pointed out in his book that in some teaching, particularly in teaching writing, students write a composition in the classroom which the teacher corrects and hands back the next day covered in red ink. The students put the corrected pieces of work in their folder and rarely look at them again. This situation can be found in some schools in Indonesia. 
That kind of activity in teaching Language teaching is considered as Traditional Teaching (TL) method. Dealing with student's improvement in learning language, especially in writing skill, there is shifting happen in Educational field. The shifting here is from TL method into Cooperative Learning (CL) method. There are several definitions of CL suggested by some researchers. One of the definitions is pointed out by Felder and Brent (2007). They suggested that CL refers to students working in teams on anassignment or project under conditions in which certain criteria are satisfied,including that the team members be held individually accountable for the completecontent of the assignment or project. From this definition, students are not working alone, individually. They work within a group which has the same goal.

Another definition of CL is suggested by Slavin in Syafini and Rizan (2010). He describes CL as students working in small groups and are given rewards and recognition based on the group's performance. Compare to the CL, TL has less advantage in the process of learning. It is in line with the statement suggested by Felder and Brent. They say:

“ relative to students taught traditionally-i.e with instructorcentered lecture, individual assignments, and competitive gradingcooperatively taught students tend to exhibit higher academic achievement, greater persistence through graduation, better highlevel reasoning critical thinking skills, deeper understanding of learned material, greater intrinsic motivation to learn and achieve, greater ability to view situations from others' perspectives, more positive and supportive relationships with peers, more positive attitudes toward subject areas, and higher self-esteem" (Felder and Brent, 2007). 
When the teachers are using Traditional Learning, the students are asked to accomplish the task individually. There will be competition among them. The fastest learners will get more success than the slow ones.

Writing plays its big role in expressing students' idea. Hence, writing is still considered as the important skilled that should be taught to the students. The skill of expressing oneself in the form of writing has been the aim of many teachers to cultivate in their students (Krause 1994).

In traditional learning, writing is assessed merely by evaluating the product of students' writing. They submit their writing to the teacher and the teacher will correct them and give it back. The only aspect which is evaluated is only the text produced by the students.

In cooperative learning, the students are not depending on the teacher. They are not merely listening to the teachers' lecture. They actively participate in the classroom activity. Syafini and Rizan (2010) mentions that in group works sometimes the participation of the group members is not equal and there are group members who indulge on a free ride without contributing the group work and objective. in one group there are different students with different characteristic. This characteristic that defines the different participation of the students.

There are some techniques under the umbrella of Cooperative Learning. They are Group-Investigation, Student Teams Achievement Division (STAD), Learning Together, Jigsaw, Murder and Write-pairsquare (Jacobs et al, 1999). All of them are suitable to be implemented in the Language Teaching. I am interested in Write-pair-square in teaching writing to my students. The reason is because it covers both group and pair work. Moreover, it seems like it is preferable in improving their 
writing skill. Working in groups not only increases students' active participation but also build their social skill development, improves communication, enhance the independence and accountability. Hence, using Cooperative Learning through Write-pair-square is likely useful to be implemented in my classroom.

However, in the real education field in Indonesia in which we can see it from the existing schools whether they are public or private, general or vocational, and primary or secondary schools, we can still easily find that traditional learning activity is still used in teaching learning process. We cannot simply say that traditional teaching is not good. However, many researchers have conducted and find that traditional learning is not adequate enough to meet the students' need. Campbell in Syafini and Rizan (2010) suggested that rote learning has been a common practice in today's educational scene in Language Learning. Hence, in this study, I pick a Cooperative Learning implementation to prove the previous study about the effectiveness of using CL in Language Teaching.

Students supposed to involve in every activity in the classroom actively. The fact happens in the field yet is different from the theory. Some students are open to the teachers and the rests are not. Syafini and Rizan (2010) suggested that xtroverts generally produce more action with fewer thoughts whereas introverts produce numerous thoughts with little action. The theories above are the ideal situations that actually should happen in education field. However, the facts in the real field are sometimes still far from the ideal ones. They are still many problems happen in making the harmony between theories and facts. Considering the facts that different from the ideal situation, I think it is needed to 
conduct a study about how to overcome this problem. Therefore, I need to give it a try on using Cooperative Learning to improve students' active participation and writing skill.

Related to the background above, the researcher formulated the research problem as follows: (1) What problems are faced by the Tenth Graders of SMA Kesatrian 2 in participating and writing a descriptive text? (2) How is a write-pair-square strategy implemented in the classroom activity? (3) How is the students' participation improvement when they are taught by using a write-pair-square strategy? (4) How is the learners' achievement in writing descriptive text improved by using a write-pair-square strategy?

\section{General concept of cooperative learning}

Many people see the description of a classroom that there is one teacher standing in front of the students. They will explain the students about the subject that he masters. While the students are sitting nicely in front of the teachers, and listening carefully what the teacher explains. The teacher asks the students not to make any noise. It is a good method when it is needed. Moreover, the assessment of only focuses on the product without any careful attention on the process.

From the ideas above, it can be concluded that in Cooperative Learning, the world of education is not only about giving the material to the students. It also covers the knowledge about socializing with the world. If people only care about themselves they cannot live in social world. It also happens in the classroom. If students merely focus on themselves, they will not interact with their friends. They even 1 compete each other to be the best. Sometimes they need to do something 
individually to learn how to survive if there is nobody they can depend on. However, if it happens all the time, they will be individualistic student. It will be difficult for them to interact since they used to work individually.

\section{Element of cooperative learning}

There is a difference between simply having students work in group and structuring groups of students to work cooperatively. This is supported by Roger and David (2009). They suggest that a group of students sitting at the same table doing their own work, but free to talk to each others as they work, is not structured to be a cooperative group, as there is no positive interdependence. It means that not all group work is cooperative learning. There are some elements of Cooperative Learning suggested by Roger and David (2009), they are; positive interdependence; individual accountability; face-to-face promotive interaction; appropriate use of collaborative skills; and group processing. In this part the elements of cooperative learning will be discussed further.

1. Positive Interdependence

Every student gets involved in any activity. In their book, Roger and David (2009) suggest that within cooperative learning situations, students have two responsibilities: 1) learn the assigned material, and 2) ensure that all members of the group learn the assigned material. From this characteristic, it is clear that the material still something important to be learned.

2. Individual Accountability

Individual accountability occurs within the interdependence. The students must feel that they are each accountable for helping to complete 
a task for mastering material (Joyce: 2010). Each student is responsible for a specific portion of a task. If there is a 'hitchhike', there will be no productive work.

\section{Face-to-face Promotive Interaction}

Cooperative learning is conducted by asking the students to work in groups. This activity results in promotive interaction. It can be defined as individual encouraging and facilitating each others' efforts to achieve, complete tasks, and produce in order to reach the group's goals. In the positive interdependence, students will feel that they need each others. In the process of helping each others, they will interact. Roger and David suggest that by using face-to-face promotive interaction, learning becomes active rather than passive (Roger and David: 2009). Discussion of the ideas happens in each group. The discussion will make the students interact each other.

More over Cooperative team helps students learn to value individual differences and promote more elaborate thinking. The heterogeneous in the groups make the students think differently. However, they have to make one goal so they will negotiate and draw a conclusion. This activity need good interaction to get one deal of the theme discussed within the group.

4. Appropriate use of Collaborative Skills

Cooperative learning makes the student master the skills for working together effectively. They are able to stay on task, summarizing, and recording the ideas. They also can maintain the skills by encouraging each others. Therefore, the teachers need to do something in order the students can learn effectively. These efforts can be done by giving them the appropriate treatment. Roger and David (2009) suggest that ways to 
foster skill development include teaching modeling, brainstorming characteristic of 'good' skills, direct practice, process observing, and reflection. These activities will support the students to develop and maintain their skills.

Being good in socialization is not an easy job. Students have different characteristic. Making them work and interact in the same time is not that easy. Roger and David (2009) state that in order to coordinate effort to achieve mutual goals, students must; 1) get to know and trust each other; 2) communicate accurately and unambiguously; and 3) accept and support each other; 4) resolve conflict constructively. When we place the unskilled students in a group and simply ask them to cooperate, there is no guarantee that they will do it. We are not burn with automatically have the instinct to socialize. All we are doing is learning as well as the students. We must teach them how to do that step by step.

\section{Group Processing}

The main activity in cooperative learning when the students have a discussion. In this process, they will learn whether they do effectively or not. They will find out who is involved and which one is not. Roger and David (2009) suggested that an effective group work is influenced by whether or not groups reflect on how well they are functioning. The function of group will run effectively if they share their idea and interact within the groups.

This group processing is an identifiable sequence of events taking place overtime, and process goals refer to the sequence of events instrumental in achieving outcome goals (Johnson \& Johnson: 1991). Therefore, this kind of learning method needs time to be investigated and the concern is not the product. Though the product is expected to prove 
the improvement of the students that is not the main point. The point is students can learn something in the process of cooperative learning for their betterment.

Based on the situation above, I conduct the study to apply the Cooperative Learning in my class in order the students are able to work not only individually but also in group.

\section{Write-pair-square}

Cooperative learning aims at leading the students to work in groups. It can be loosely categorized by the skill that each enhances (Barkley, Cross and Major: 2005). It means that it can be done by conducting several strategies under the umbrella of Cooperative learning. Each of them includes the number of potential structures to guide the development of a cooperative learning exercise. It is in line with the statement about the technique of cooperative learning. Each strategy can be developed to fit within multiple categories by considering the needs of the student.

One of the strategies is Write-Pair-Square. This is a four-step discussion strategy that incorporates with time and aspects of cooperative learning. Students and teachers learn to listen while a question is posed (Joyce: 2010). The students need time in doing the activity. It requires the skill of listening and gives more attention to teacher's instruction.

Write-pair-square is developed byKagan (1994). This strategy consists of three steps:

1. Write

The teacher asks question on the certain issues related to the learningmaterial. After that, the students are required to think about 
the issues individually. In this step students should work individually. They write their opinion about the given issue by the teacher.

\section{Pair}

The students are grouped in pair to discuss what they have been thinkingon the first step. In this step, students share their answer on the proposed question, or share theidea on the identified problem. Teacher usually allocates 4 or 5 minutes to work in pair. The students share their idea with the partner and make pair work. The discussion is needed after sharing. They complete their opinion each other. They take the good idea and construct a pair work.

\section{Square}

To share what they have learnt, in this step, teacher asks one student ofthe pairs to form a bigger group. In this way, all the students within the group are expected to be ableto share the idea. They share their idea and finally make a group work. They have to compose the final draft after sharing and discussing the topic. Each pair presents its pair work and by discussing they will find which idea is good and complete with another good idea.

The response is something that becomes the key of this learning process. This strategy provides students with the opportunity to reflect on the question posed and then practice sharing and receiving potential solutions. By doing this step, students are supposed to be critical and creative to respond a question dealing with the theme given by the teachers. 


\section{Research Method}

In this research, the writer applied qualitative approach to identify the use of writing-pair-square in improving students' active participation in writing descriptive text. In completing this research, the writer collected data and information from the main source, namely field research. This term referred to the efforts in obtaining the empirical data from the subject of the research. The writer also conducted the activity of gathering information from library facilities such as references and books which supported the efforts in conducting this research. The writer decided to carry out an action research in SMA Kesatrian 2 Semarang as the writer had been teaching there and wanted to know how is the effective way in using a write-pair-square to improve students' active participation and their writing ability.

The research design of this study was Action Research. It took two cycles. Each cycle consisted of three meetings excluded the pre and posttest. Each cycle had four steps; they were planning, acting, observing, and reflecting. The place of this research was at a private school. It is SMA Kesatrian 2 Semarang at Gajah Raya Street number 58, Semarang. The research was conducted in the second semester of the academic year of 2012/2013. The pre-cycle test was conducted on April, 24 2013. The second cycle was conducted on April, 302013 - May, 8 2013. Second cycle was conducted on 14-21 May 2013 and post test 2 was conducted on May, 222013.

The study of action research was involving a group of students as the subject of investigation. This action research was done at SMA KESATRIAN 2 SEMARANG. This school is located at Jalan Gajah 
Raya Number 58, Semarang. I conducted this action research in classX.3. There were 13 males and 17 females.

In this action research, some instruments were used in form of observation sheet, outsider observer, field notes, rubric of students' active participation, students' observation sheet, and test. Observation sheet was used to describe the exact situation during the research was conducted. It was be used by the outsider observer. He filled the observation sheet while doing the observation. I collaborated with one of the teachers in my school to do the observation during this research was conducted. The data analysis in this study consisted of observation sheet, students' participation scoring, students' observation sheet, and writing test.

\section{Findings and discussion}

The preliminary research was conducted before the research was undertaken. I observed the students while I was teaching them. I had taught them for almost two semesters. According to the teaching experience and two semesters activities, I could identify the problems are faced by the students in learning English. Some of the problems are; (1) lack of learning sources; (2) lack of motivation; (3) family background; (4) lack of interest; (5) lack of motivation; (6) lack of practice; (7) no support from the environment; (8) lack of participation and (9) low competence.

Those problems make the students' ability in writing skill is unsatisfying. In this study I concerned with the problems dealing with lack of participation and writing problems. The following paragraphs are the discussion about those two problems. 
The pre-test was conducted in order to know the students' prior achievement in writing description text. Moreover, it was given to dig students' weaknesses in writing. The pre-test was given to the students on Wednesday, $24^{\text {th }}$ April 2013, before the research was conducted. The students were asked to produce a description text after given a short explanation and sample about descriptive text. The results of the students' writing were analyzed based on the rubric of scoring writing test. The time allotment given was 90 minutes. The result of this pre-test would be compared with the result of the test after students were given treatments. The aim of this comparison was to determine the improvement of students' writing skill of descriptive text.

After administering the pre-test, the result was analyzed to get the students' score. The result of this pre-test analysis would underline the process of planning for the first cycle. The result of the pretest was attached in the following table 1 (appendix 11). The following table was the summary of the pre-test result.

Table 1. The Summary of Pre-test Result

\begin{tabular}{|c|c|c|c|c|c|c|}
\hline Category & Organization & Content & Grammar & Punctuation & Style & Total \\
\hline Mean & 13.17 & 19.80 & 14.83 & 3.70 & 11.70 & 63.27 \\
\hline$\%$ & 65.83 & 66 & 59.33 & 74 & 58.83 & 13.33 \\
\hline
\end{tabular}

Based on the data presented in appendix 11, the mean score was calculated as follows.

$$
\begin{aligned}
\text { mean } & =\frac{\sum x}{n}=\frac{\text { The total score of the descriptive text }}{\text { the total number of students }} \\
& =\frac{1898}{30}=63.27
\end{aligned}
$$


According to the pre-test analysis, the average of the students' result was 63.27. The passing grade of writing test was 75. The percentage of the student that achieved the passing grade was 13\% (4 students). Using the same formula, the mean of each category was calculated. The result showed that the mean of organization was 13.17, content was 19.80, grammar was 14.83, punctuation was 3.70, and style was 11.77. This score then would be analyzed to get the description of their competence in writing descriptive text.

The first Post-test was conducted after the third meeting of cycle 1. The students were given an answer sheet and asked to write a descriptive text about animal. The time allotment was 45 minutes. After giving the material, worksheet and exercise using write pair square strategy, the students were expected to produce a good descriptive text. The students' results of writing were evaluated and it was constructed into a result table. It was attached in the appendix 12. The following table 2 was the summary of Post-test 1 result

Table 2. The Summary of Post-test 1 Result

\begin{tabular}{|c|c|c|c|c|c|c|}
\hline Category & Organization & Content & Grammar & Punctuation & Style & Total \\
\hline Mean & 15.17 & 22.07 & 17.60 & 3.90 & 11.60 & 70.23 \\
\hline$\%$ & 75.83 & 73.56 & 70.4 & 78 & 57.5 & 70.23 \\
\hline
\end{tabular}

Based on the students' writing result table, it was found that the average score of students' writing in the first post-test was 70.23. The students that achieved the passing grade of writing test were 18 students (70.23\%). The same formula was applied to analyze each category in writing rubric. From the calculation, it was found that the mean of 
organization was15.17. In other words the students' organization competence achieved by them was $75 \%$ if it was compared to the maximum score. The result of mean score and achievement percentage of content, grammar, punctuation, and style was respectively 22, 07 (73.55\%); 17.60 (70.4\%); 3.90 (78\%); and 11.50 (57.5\%). Generally, there were improvement found based on average score and each rubric category except in style category.

The reflection was constructed based on the process during the actions and observation was undertaken. The reflections were as follows.

1. Students' participation result showed that the students' participation was still in poor category.

2. Based on the result of students' writing, it was found that they were still poor in category style. It was because when they were composing a descriptive text, almost all of the students were confused in choosing the vocabulary. Sometimes they did not know the English word of the word that they wanted to write. Sometimes they misused the English word. For example they used 'see' instead of 'watch' in 'I see television with my brother' while actually he meant 'I watch television with my brother'.

3. They found difficulty in making a group in the process of 'square'. It was because the instruction was not clear enough for them. Before they did the 'write pair square' I only informed them that they were going to work individually, in pairs and in group. However, I did not give instruction how to make a group after they shared with their partner. This lack of information made them took quite long time to make a group. 
4. In 'pair' step, they find difficulties about how to make the result of sharing. Some of them wrote the point and others wrote in form of paragraph. It made the students confused since there was no clear instruction about the form of 'pair' discussion result.

5. In doing the individual work, they still look at their friends' result. It could be found when the students were doing worksheet and in the process of 'write' in write pair square strategy. When they were still having discussion in writing their opinion, it was useless since after they did 'write' process they would have 'pair' work where they would discuss their own work to their pair.

6. In doing the 'square' process, it was expected that all of the students would participate actively in sharing and discussing the topic. However, in fact there were only some students who controlled the discussion while other members were only kept silent without giving any idea. Some of them did not contribute because they did not know what to say but the others seemed not too enthusiastic in taking a part.

7. By having some worksheet in each material, they complained that they were bored of doing the written exercise.

Based on those reflections, I decided to conduct the second cycle. The planning would be based on the problems in the reflection of this cycle. I expected by having the second cycle there would be improvement.

The second Post-test was conducted after the third meeting of cycle 2. The students were given an answer sheet and asked to write a descriptive text about person. The time allotment was 45 minutes. After giving the material, worksheet and exercise using write pair square 
strategy, the students were expected to produce a good descriptive text. The students' results of writing were evaluated and it was constructed into a result table. It was attached in the appendix 13. The following table was the summary of Post-test 2 result.

Table 3. The Summary of Post-test 2 Result

\begin{tabular}{|c|c|c|c|c|c|c|}
\hline Category & Organization & Content & Grammar & Punctuation & Style & Total \\
\hline Mean & 18.17 & 23.00 & 19.00 & 4.07 & 12.85 & 77.07 \\
\hline$\%$ & 90.83 & 76.67 & 76 & 81.33 & 51.33 & 76.67 \\
\hline
\end{tabular}

Based on the students' writing result table, it was found that the average score of students' writing in the second post-test was 77.07. This number was higher if compared to the average score in cycle 1. It showed that the students' writing competence was improved. The students that achieved the passing grade of writing test were 23 students (76.67\%). The number of students that achieved the passing grade was also increased.

In the beginning, most of them were passively participate in classroom. However, by applying write pair square strategy they got opportunity to willingly participate and involved themselves in classroom activity. To make it clear in understanding the research result, the observation result of the activity was pictured in the following (Figure 1): 


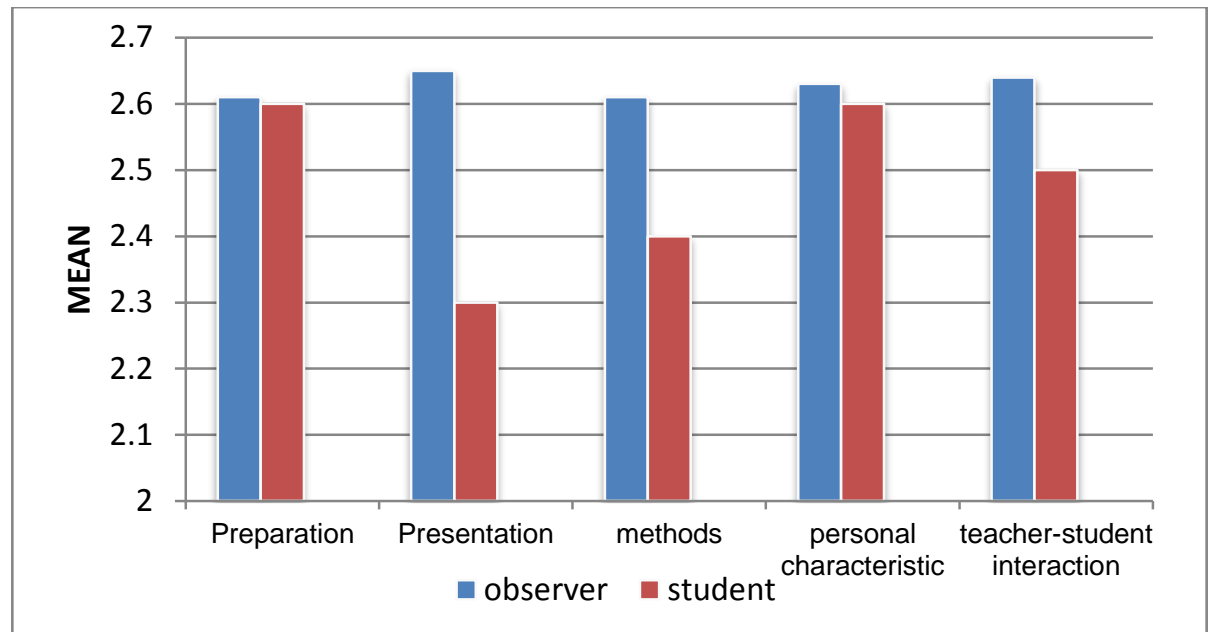

Figure 1 The result of Research observation by Observer and students.

was in line with what students thought. It meant that there was a balance between the observer's opinions with students' point of view. The observer observed started before and during the research was done. Then the result was derived from the calculation of the average score derived from each meeting. It was done to find the changes of each meeting. In the end of the research the students were given an observation sheet to make sure that the data was taken from both sides, from observer's and students' opinion.

Another issue in this research was students' active participation. The following was students' development of participation that had been observed before and during the research. 


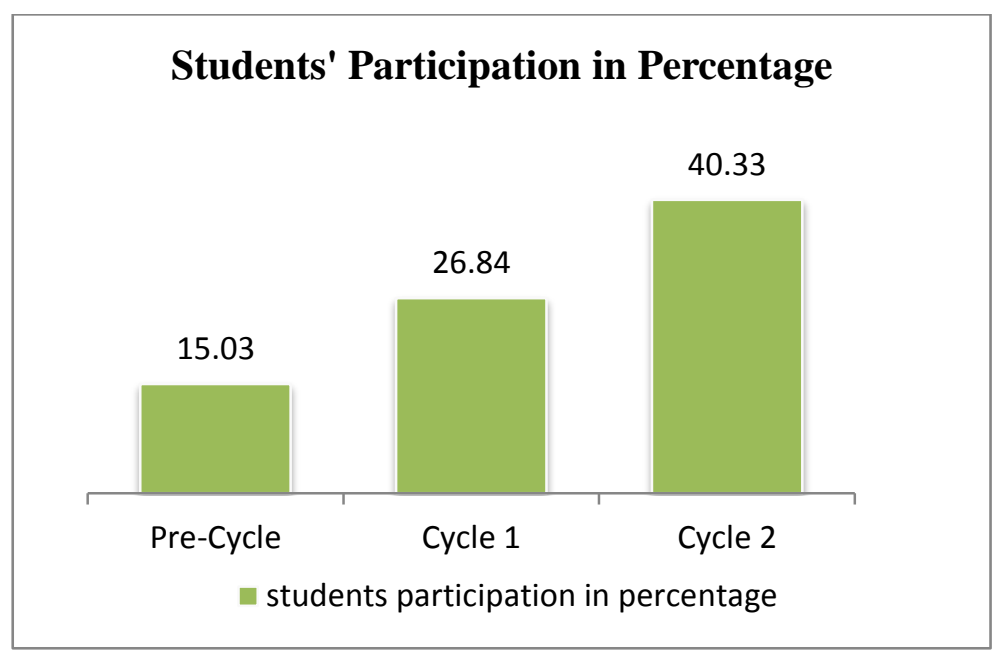

Figure 2 The result of Research observation by Observer and students.

Table 4. The Classification of Students' Achievement

\begin{tabular}{|c|c|}
\hline Percentage & Level of Achievement \\
\hline $67-100$ & Excellent \\
$34-66$ & Good \\
$0-3$ & Poor \\
\hline
\end{tabular}

Based on the diagram above, it was showed that students' participation in pre-cycle was $15.03 \%$; first cycle was $26.84 \%$ and second cycle was $40.33 \%$. Based on the classification of achievement table (Table 4), the level of achievement of students' active participation was poor in Pre-cycle and Cycle 1 and improved to Good in cycle 2.

Besides participation, another concern in this research was students; competence in writing descriptive text. In the beginning, students were expected showed change during the research or in other words they were expected to improve their competence after being taught 
using write Pair Square strategy. The following diagram showed clearly the development of students' writing competence from pre-cycle to the end of cycle 2 .

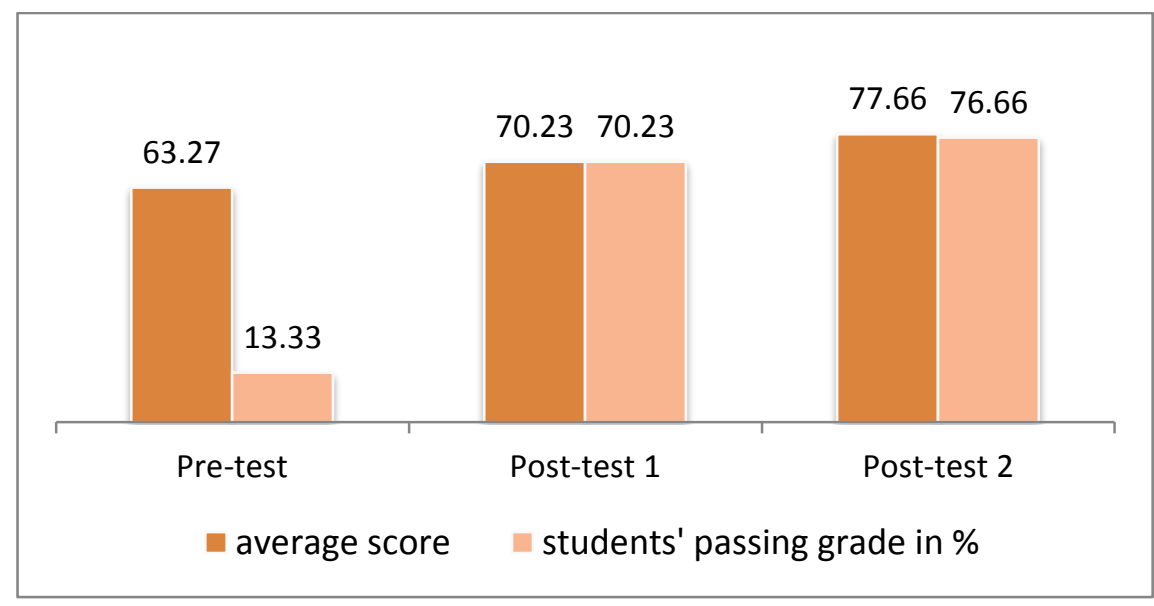

Figure 3 The development of students' writing descriptive competence

The Figure above showed that students' writing competence in pre-test was improved both the average score and the number of students that achieved the writing passing grade. The mean score in pre-test was 63.27 and the number of students that achieved the passing grade was $13.33 \%$ from the total number of the student. The average score of post-test 1 was 70.23 and there were $70.23 \%$ students achieved the passing grade. The last post-test's average score was 77.66 and there were $76.67 \%$ students achieved the passing grade.

The development of students writing competence had some category that could be seen their improvement. Each category had different achievement but generally they were improved. The following diagram showed the development of students' each category competence in writing descriptive text. 


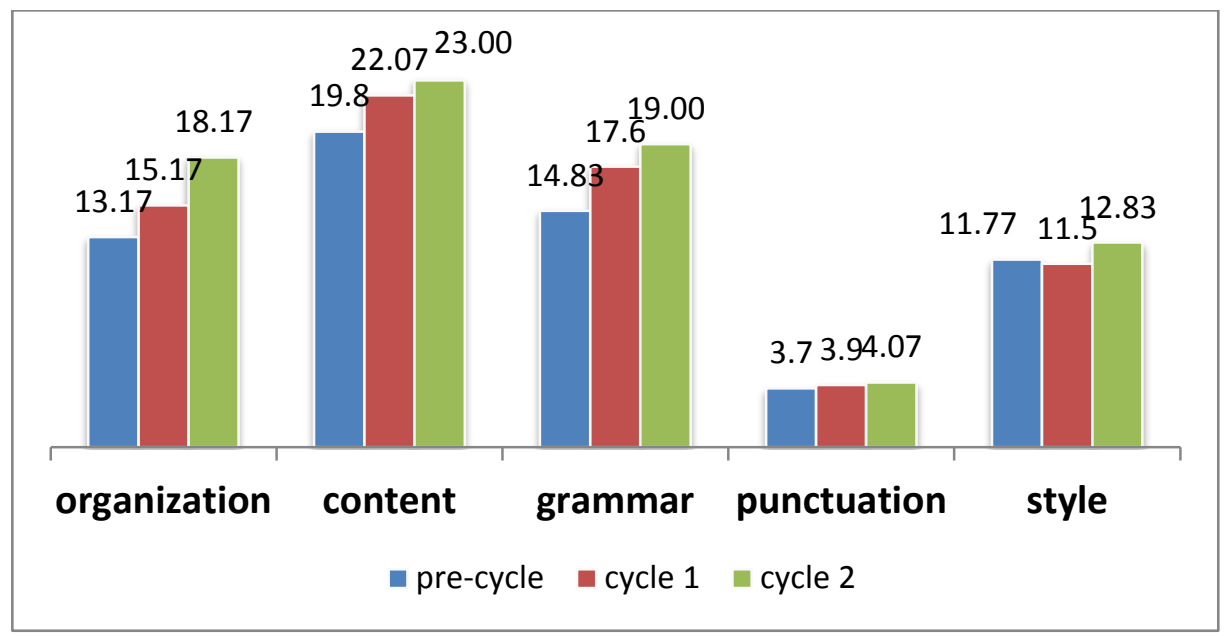

Figure 4 The development of students' writing descriptive competence in each assessment category

From the diagram above it showed that students' competence in each assessment category was generally improved. The organization's average score in pre-cycle was 13.17; cycle 1 was 15.17; and cycle 2 was 18.17. The content's average score in pre-cycle was 19.80; cycle 1 was 22.07; and cycle 2 was 23 . The average score of grammar competence in pre-cycle was 14.83; cycle 1 was 17.6; and cycle 2 was 4.07 . The average score of style in pre-cycle was 11.77 ; cycle 1 was 11.50 ; and cycle 2 was 12.83 .

\section{Conclusion}

Based on data analysis which was discussed, the researcher concluded that:

This study concerns with the use of write-pair-square strategy to improve students' active participation in writing descriptive text. Based on the results of the study, the conclusions are as follows. 
Firstly, the main problems faced by the students in the preliminary research were the lack of participation in classroom activity and writing a text especially in grammar and vocabulary.

Secondly, the Write-pair-square was implemented through action research. It consisted of pre-cycle, cycle 1 and cycle 2. In Cycle 1 and Cycle 2 there were four steps they were planning, acting, observation and reflection. Write-pair-square was done in the acting step. It consisted of three activities; write, pair, and square. There was a pre-test and post-test in each cycle.

Thirdly, the implementation of Write-pair-square strategy in the classroom

activities had developed students' active participation. The percentage of students' participation had developed from $15.33 \%$ into $40.33 \%$ and based on category they are developed from poor into good category.

Fourthly, the implementation of Write-pair-square strategy during the research had developed students' writing descriptive competence. This strategy had also improved the percentage of the students that gain the passing grade.

\section{References}

Abu, R. B. 2008. The Effects of Cooperative Learning Methods on Achievement, Retention, and Attitudes, of Home Economics Students in North Carolina.Teaching Language Journal.Vol 12, 3 . Available online at: scholar.lib.vt.edu/ejournals/JVTE/v13n2/Abu.html [accessed on 13-13-12] 
Anderson, M., and Anderson, K. 2003.Text Type in English 1. South Yarra: Macmillan Education.

Anderson, Text Type 2. South Yarra: Macmillan Education.

Arikunto, S. 2002. ProsedurPenelitianSuatuPendekatanPraktek. Jakarta: RinekaCipta.

Bonner, M. 1994.Step into Writing. A Basic Writing Text. London: Edison Wesley Longman.

Brown, H. D. 2001. Teaching Principles: An Interactive Approach to Language Pedagogy, Second Edition. London: Addison-Wesley Longman

Brown,H.D.2004.LanguageAssesmentPrinciplesandClassroomPractices. New York: Pearson Education.

Brown, J D. 1988. Understanding Researchin Second Language Learning.Cambridge:Cambridge University Press.

Burns, A. 2010.Doing Action Research in English Language Teaching.A Guide for Practitioners. New York: Routledge.

Cohen, L., Manion, L., and Morrison, K. 2007. Research Methods in education. New York: Routledge.

Duin, A. H. 2007. Implementing Cooperative Learning Groups in The Writing Curriculum. Journals of iupui Education.Vol. 3, 12.Available online journals.iupui.edu/index.php/teachingwriting/.../778 - United States [accessed on 12-11- 2012 at 2 pm]

Felder, R. M., and Brent, R. 2007.Cooperative Learning. Active participation: Models from analytical science, ACS Symposium Series 970, Chapter 4, pp. 34-53. Washington DC: America Shemical Society. Available online at: http://www.ydae.purdue.edu/lct/hbcu/documents/Activelearning engineering.pdf [accessed on 13-12-12]

Harmer, J. 2002.The Practice of English Language Teaching $3^{\text {rd }}$ Edition . London: Longman.

Harmer, J. 1998.How to Teach English. $7^{\text {th }}$ impression 2001. Edinburg: Pearson Education Limited.

Harmer, J. 2004.How to Teach Writing. Edinburg: Pearson Education Limited.

Jacobs et al. 1997. Learning Cooperative Learning Via Cooperative Learning: A Sourcebook of Lesson Plans for Teacher Education on Cooperative Learning. Singapore: SEAMEO.

Jacobs, G.M., and Yong, S. h. 2004. Using Cooperative Learning To Teach Via Text Types. The Reading Matrix.Vol. 4, No. 2, 
September.

Available

online

at:

http://www.readingmatrix.com/articles/jacobs_yong/articlepart1.pdf [accessed on 1-12-13]

Joyce, B. 2010.A guide to Cooperative Learning. The Electronic Learning Community: Prince George's Country Public School. Available online at: http://www.google.co.id/search?hl=en\&tbo=d\&noj=1\&spell=1 $\& q=$ A + guide+to+Cooperative+Learning. + The+Electronic + Lear ning+Community:+Prince+George $\%$ E2\%80\%99s+County+Publ ic + School\&sa $=$ X\&ei $=1$ HwXUeP4M4XXrQfsuYDoCw\&ved $=0$ CCsQvwUoAA\&biw=1024\&bih=559 [accessed on 22-12-12]

Lee, P. 2005. Students' Personality Type and Attitudes Toward Classroom Participation. Los Angeles: CATESOL State Conference. Available online at: http://www.catesol.org/Lee1.pdf [accessed on1-12-13]

Lorna, K. J. 2010. Active participation.Article at School of Education, Indiana University Bloomington page 1-4. Available online at: www.texascollaborative.org/activelearning.htm [accessed on 23$11-12$ at 3 p.m]

Martin, C. 1985. Exploring American English. New York: Macmillan Publishing Company.

Murray, D. M. 1972. Teach Writing as a Process Not Product. The Leaflet.November page 11-14. Available online at: www.english.ohiou.edu/.../teach_writing_as_a_process_not_pro $\mathrm{duct} /$ [accessed on 11-12-12]

Nakamol, Nudee et al. 2010. Cooperative Learning and Writing ability Improvement.IJES Journal.The $2^{\text {nd }}$ International Conference on Humanities and Social Sciences. Available online at: http://www.krepublishers.com/02-Journals/IJES/IJES-03-0-00011-Web/IJES-03-2-000-11-ABST-PDF/IJES-03-2-103-11-124Ofodu-G-O/IJES-03-2-103-11-124-Ofodu-G-O-Tt.pdf [accessed on 22-12-12]

NBSA (National Board of School Accreditation). 2006. Content Standard for Senior High School. Jakarta: IntanPariwara.

Nunan, D. 2003.Practical English Language Teaching, First Edition. Singapore: McGraw-Hill.

Richard, J. R.2002. Methodology in Language Teaching.An anthology of Current Practice. New York: Cambridge University Press.

Roger, T and David, W.J. 1998. Cooperative Learning: Two Heads Learns better than One. Transforming Education.Page 34. 
Available online at: www.context.org > About In Context > Transforming Education [accessed on 23-11-12 at 3:12 pm]

Roger, T and David, W.J . 1994. An Overview of Cooperative Learning: Creativity and Colaborative Learning. Baltimore: Brooke Press.

Schunk, D. H. 2008. Learning Theories: An Educational Perspective, Sixth Edition. Boston: Pearson Education.

Syafini and Rizan, T. N. 2010.The Effects of Cooperative Learning in Enhancing Writing Performance. Available online at: http://www.ukm.my/solls09/Proceeding/PDF/Shafini.pdf [accessed on 11-12-12]

Yoder, J.D., and Hochevar, C.M. 2005. Encouraging Active participation can Improve Students' Performance on Examinations.Vol.32, No.2.available online at:

http://www.vcu.edu/cte/workshops/workshop_list/references/Yo der_\%26_Hochevar.pdf [accessed on 11-12-12 ] 